\title{
Cyclization-endoperoxidation cascade reactions of dienes mediated by a pyrylium photoredox catalyst
}

\author{
Nathan J. Gesmundo and David A. Nicewicz
}

\section{Letter}

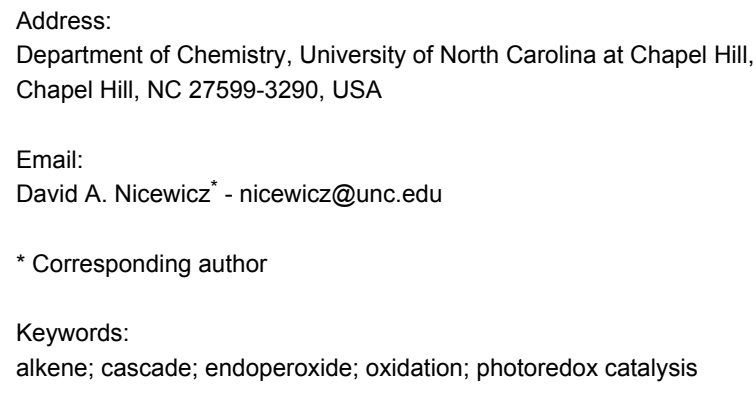

\section{Email:}

David A. Nicewicz* - nicewicz@unc.edu

* Corresponding author

Keywords:

alkene; cascade; endoperoxide; oxidation; photoredox catalysis

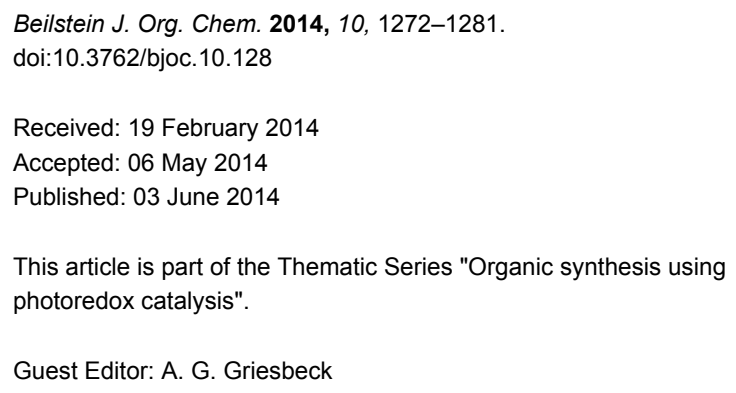

Beilstein J. Org. Chem. 2014, 10, 1272-1281.

doi:10.3762/bjoc. 10.128

Received: 19 February 2014

Accepted: 06 May 2014

Published: 03 June 2014

This article is part of the Thematic Series "Organic synthesis using photoredox catalysis".

Guest Editor: A. G. Griesbeck

(C) 2014 Gesmundo and Nicewicz; licensee Beilstein-Institut.

License and terms: see end of document.

\begin{abstract}
Triarylpyrylium salts were employed as single electron photooxidants to catalyze a cyclization-endoperoxidation cascade of dienes. The transformation is presumed to proceed via the intermediacy of diene cation radicals. The nature of the diene component was investigated in this context to determine the structural requirements necessary for successful reactivity. Several unique endoperoxide structures were synthesized in yields up to $79 \%$.
\end{abstract}

\section{Introduction}

Endoperoxides are a structurally unique class of naturallyoccurring compounds that feature a reactive cyclic peroxide moiety of varying ring sizes (Figure 1). The lability of the endocyclic peroxide $\mathrm{O}-\mathrm{O}$ bond engenders these compounds with a range of important biological functions, most notably, antimalarial and antitumor activity (e.g., artemisinin, yingzhaosu A and merulin C) [1-4]. From a synthetic standpoint, the installation of the endoperoxide moiety presents a significant challenge due to its susceptibility to reduction and for this reason, is ideally introduced late-stage in target-oriented synthesis. Additionally, many endoperoxide natural products possess architecturally complex frameworks (e.g., artemisinin, yingzhaosu A, muurolan-4,7-peroxide) [5] that pose significant synthetic challenges.
Classical approaches to the introduction of cyclic peroxides typically rely on cycloadditions of alkenes and dienes with singlet oxygen. However, ene processes can often compete, leading to complex mixtures of hydroperoxide adducts $[1,6-8]$. More recently, cyclization reactions of hydroperoxides with pendant alkenes or alkynes have been developed. Selected examples include $\mathrm{Pd}(\mathrm{II})$-catalyzed hydroalkoxylation reactions of unsaturated hydroperoxides [9], $\mathrm{Au}(\mathrm{I})$-catalyzed endoperoxidation of alkynes [10] and Brønsted acid-catalyzed enantioselective acetalization/oxa-Michael addition cascade reactions of peroxyquinols [11].

While these extant methods are effective at installing the endoperoxide functional group, our interest lay in developing strate- 


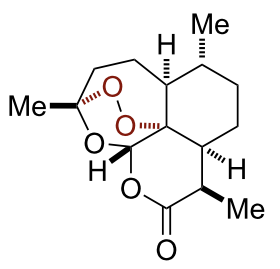

artemisinin

antimalarial activity

$\mathrm{IC}_{50} 29.8 \mathrm{mM}$

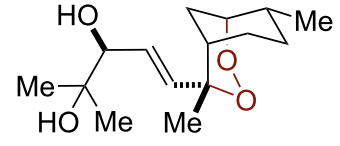

yingzhaosu $A$

antimalarial activity

$\mathrm{IC}_{50} 0.12 \mathrm{mM}$

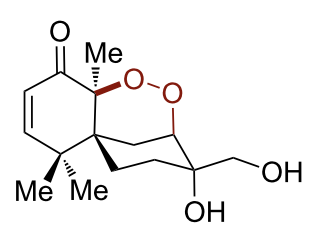

merulin $C$

BT474 cell line cytotoxicity

$\mathrm{IC}_{50} 1.57 \mathrm{mg} / \mathrm{mL}$

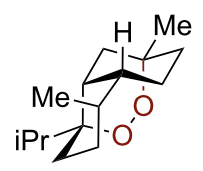

muurolan-4,7-peroxide

oxygenated sesquiterpene

Figure 1: Selected examples of endoperoxide-containing natural products.

gies that simultaneously forged both the cyclic peroxide as well as the carbon framework to rapidly build molecular complexity. For this reason, we were inspired by the work of Miyashi, who, during the course of the investigation of the cation radical Cope rearrangement, discovered an intriguing endoperoxide-forming reaction (Scheme 1, reaction 1). Upon exposure of 1,5 and 1,6dienes to catalytic quantities of 9,10-dicyanoanthracene (DCA) under UV irradiation in the presence of oxygen, bicyclic endoperoxides were obtained [12]. Formation of the 1,2-dioxanes was presumed to occur via single electron oxidation of the diene by the excited state DCA followed by either 6-endo or 7-endo cyclization modes to generate a fleeting distonic cation radical species. Interception of the distonic cation radical by triplet oxygen and back electron transfer completes the catalytic cycle. While later reports expanded the scope of this transformation modestly $[13,14]$, we felt that this strategy had potential to be a more general method. Indeed, during the course of this work, the Yoon research group disclosed a similar strategy employing $\mathrm{Ru}(\mathrm{bpz})_{3}{ }^{2+}$ as the photooxidant to effect a 5-exo cyclization/endoperoxidation cascade of bis(styrene) substrates
(Scheme 1, reaction 2) [15]. More recently, Kamata and Kim have employed this reaction manifold to forge endoperoxides from 1,2-divinylarene precursors [16].

We envisioned that the scope of this transformation could be extended to include non-styrenal dienes as well as alternative cyclization modes, provided that a potent single electron oxidant could be identified $\left(E_{\text {red }}>+1.5 \mathrm{~V}\right.$ vs SCE). Given the paucity of ground-state single electron oxidants capable of this task, we elected to employ photooxidation catalysts. Additionally, we sought to select visible light-activated organic single electron oxidants that do not readily sensitize singlet oxygen [17-19]. For these reasons, we were attracted to the use of triarylpyrylium salts, as they have excited state reduction potentials in excess of $+1.7 \mathrm{~V}$ vs SCE (Scheme 2) [20]. In addition, prior work demonstrates that these catalysts are productive in cation radical mediated $[4+2],[2+2]$, oxygenation, and rearrangement chemistry $[21,22]$. We also sought to delineate the reactivity of the diene with respect to its structure to better predict the mode of diene cation radical cyclization (5-exo vs
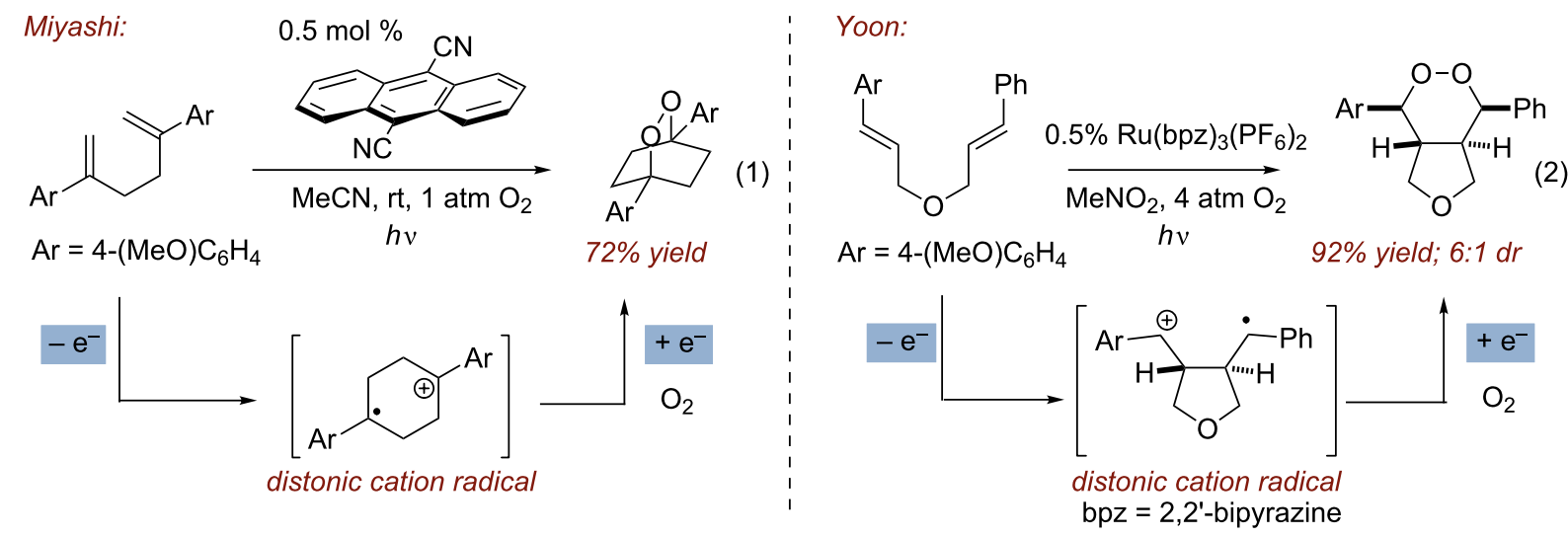

Scheme 1: Endoperoxide formation via cation radicals. In both examples, single electron oxidation is followed quickly by cyclization to form stabilized distonic cation radical intermediates. The distonic intermediates are trapped by $\mathrm{O}_{2}$ and furnish the shown bicyclic products after reduction. 

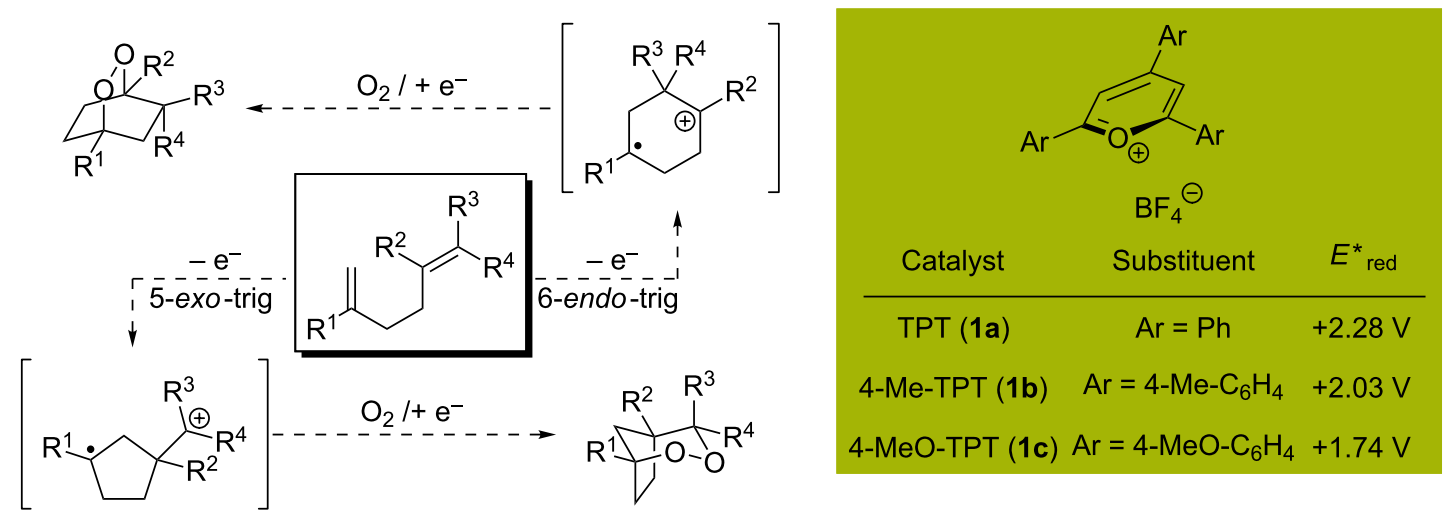

Scheme 2: Diversification strategy for endoperoxide synthesis by single electron transfer. $E^{\star}$ red Vs SCE [20].

6-endo). Herein is reported an organocatalytic photoredoxmediated strategy for the endoperoxidation of 1,5-dienes using ${ }^{3} \mathrm{O}_{2}$ to rapidly generate complex endoperoxide frameworks.

\section{Results and Discussion \\ Reaction optimization}

We began our investigation into endoperoxidation conditions with diene $\mathbf{2 a}$ as the substrate as it contained both a styene and an aliphatic alkene. Using catalyst $1 \mathrm{c}$ in DCM at $-41{ }^{\circ} \mathrm{C}$ under irradiation with $470 \mathrm{~nm}$ LEDs afforded endoperoxide 3a in 40\% yield after 5 hours (Table 1, entry 1). The observed endoperoxide was attributed to a 5-exo cyclization mode of the diene cation radical followed by capture of molecular oxygen. The use of acetonitrile as solvent gave none of the desired adducts (Table 1, entry 2). Further improvement of the chemical yield of 3a was realized by increasing the reaction concentration

Table 1: Reaction Optimization and Control Experiments.

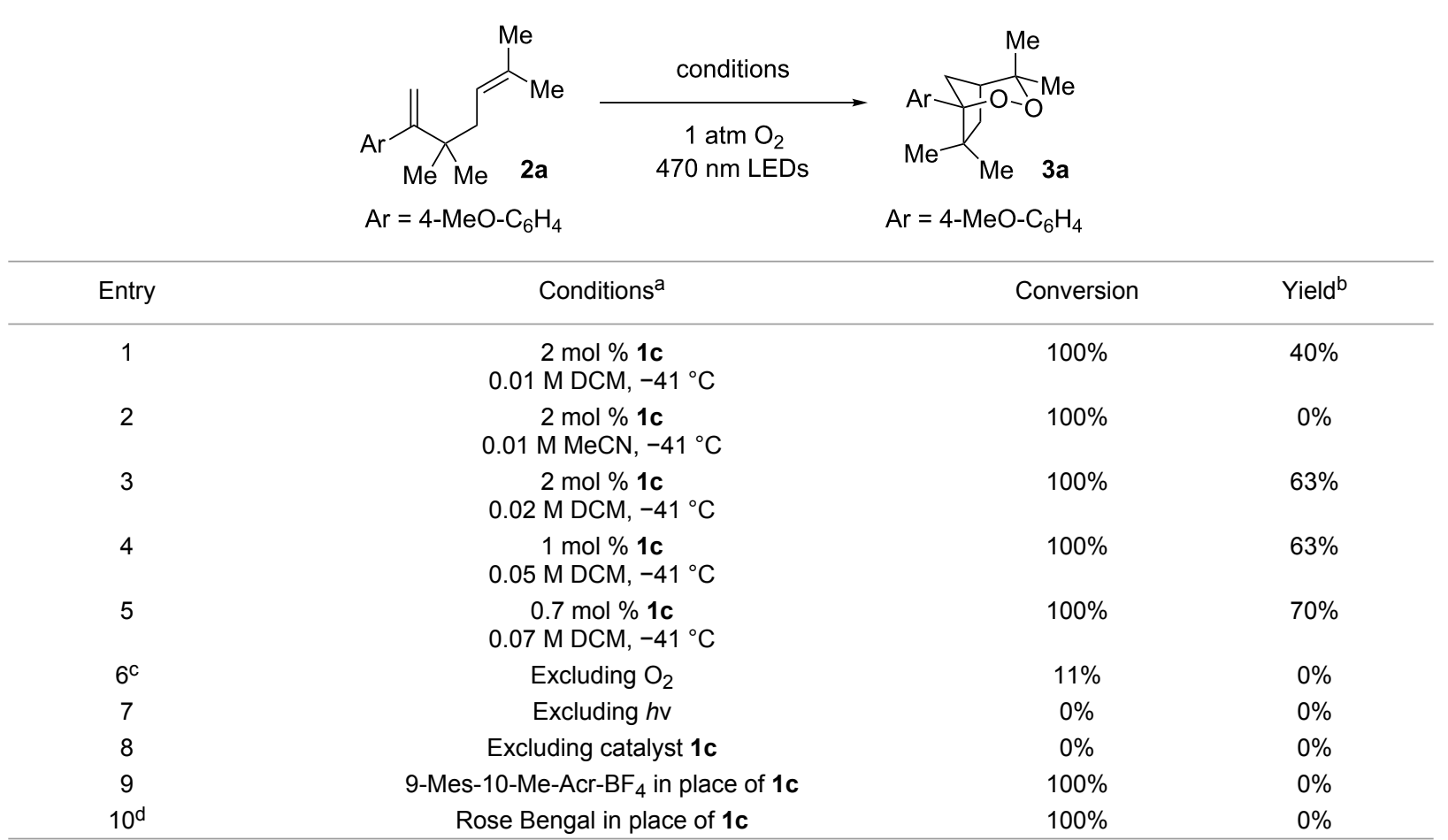

All reactions carried out in oxygen-saturated solvents unless otherwise noted. ${ }^{\mathrm{a}}-41^{\circ} \mathrm{C}$ found to be the optimum temperature during initial substrate/ reaction optimization. bYields with respect to $\left(\mathrm{Me}_{3} \mathrm{Si}\right)_{2} \mathrm{O}{ }^{1} \mathrm{H}$ NMR internal standard. CReaction carried out under $\mathrm{N}_{2}$ atmosphere in DCM. ${ }^{\mathrm{d}} \mathrm{Reaction}$ carried out in oxygen saturated $\mathrm{MeOH}$ at room temperature using a white flood lamp. 
(Table 1, entries $3-5)$, resulting in a $70 \%$ yield $\left({ }^{1} \mathrm{H}\right.$ NMR) of the endoperoxide (Table 1 , entry 5 ). In all reactions, substrate conversion was $100 \%$, with the remainder of the mass balance in all cases representing oxidative decomposition pathways. When $\mathrm{O}_{2}$ was excluded from the reaction (Table 1, entry 6), none of the endoperoxide was observed. Not surprisingly, exclusion of light or catalyst $\mathbf{1 c}$ from the reaction (Table, 1 entries 7 and 8 respectively) resulted in no product formation. Interestingly, when 9-mesityl-10-methylacridinium tetrafluoroborate, which has been used with success in other photooxidation processes [23-26], was used in place of 1c, complete consumption of 2a was observed, but 3a was not produced. Once again only oxidative decomposition pathways seemed active, this time possibly due to superoxide formation. Lastly, to exclude the intervention of a singlet oxygen mechanism, we conducted the reaction in the presence of Rose Bengal. Under these conditions, we observed only ${ }^{1} \mathrm{O}_{2}$ ene reactivity with the isoprenyl group ( $65 \%$ yield of hydroperoxide), underscoring the unique reactivity garnered by this catalyst system (see Supporting Information File 1 for hydroperoxide characterization). Suitable crystals of $\mathbf{3 a}$ provided X-ray confirmation of the endoperoxide structure (Figure 2).

We invoke a mechanism similar to that proposed by Miyashi [12] and Yoon [15] in their respective transformations (Scheme 3). Following excitation of triarylpyrylium tetrafluoroborate catalyst $\mathbf{1}$, one-electron oxidation of the 1,5-diene substrate produces localized cation radical intermediate $\mathbf{4}$ and

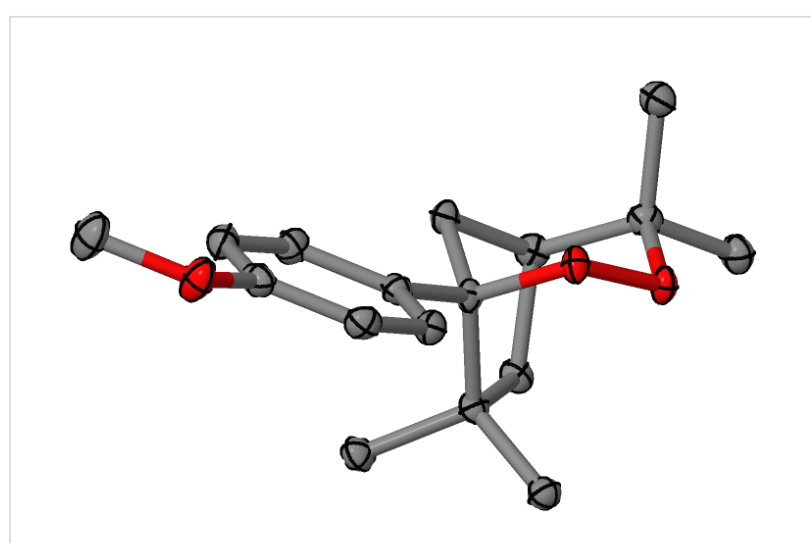

Figure 2: ORTEP of $\mathbf{3 a .}$

pyranyl radical $\mathbf{1}^{\bullet}$. Cyclization of diene cation radical 4 then forms stabilized distonic cation radical intermediate $\mathbf{5}$, which is intercepted by $\mathrm{O}_{2}$ to form $\mathbf{6}$. Single electron reduction, either from $\mathbf{1}^{\bullet}$ to regenerate active catalyst $\mathbf{1}$ or from another substrate equivalent in a chain process, forms the desired bicyclic endoperoxide.

DFT calculations suggest that the formation of the initial distonic cation radical $\mathbf{5}$ is exothermic by approximately $3 \mathrm{kcal} / \mathrm{mol}$ relative to cation radical 4 [27]. Superficially, this is rationalized by the increased substitution on 5 relative to 4 . In addition, the majority of the spin density on $\mathbf{5}$ is located on the isoprenyl group (DFT-5, Scheme 3). This may be fortuitous as

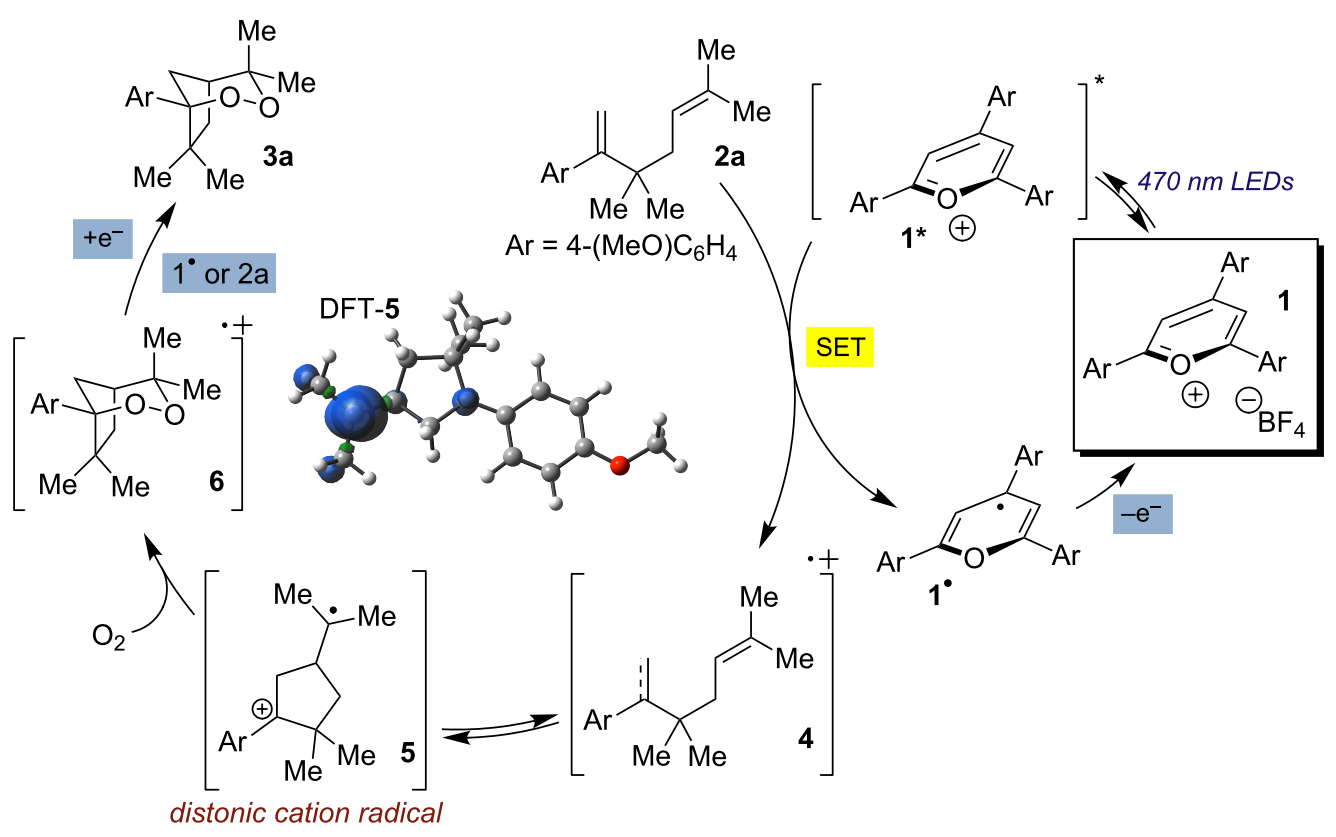


stereoselectivity in the oxygen addition step is irrelevant, whereas the opposite scenario involving a benzylic radical intermediate would require a stereospecific addition of oxygen to the same face of the cyclopentane system as the isoprenyl cation in order for endoperoxide formation to occur.

With optimized conditions identified, we sought to examine the scope of the reaction with respect to the diene structure. Miyashi's 1,5-diene (2b; $E_{1 / 2}{ }^{\mathrm{Ox}}=1.22 \mathrm{~V}$ vs SCE [12]) afforded a $50 \%$ yield of the expected endoperoxide along with $\sim 5 \%$ of a 1,4-dione, presumably from double oxidative cleavage of the 1,5-diene (Table 2, entry 1). Unfortunately, attempts to move away from $\mathbf{2 b}$ to less electron-rich dienes such as $\mathbf{2 c}, \mathbf{2 d}$ and $\mathbf{2 e}$ (Table 1, entries 2-4), failed to produce any of the desired endoperoxide products and mainly oxidative cleavage adducts were observed.

Given the lack of reactivity of this alkene substitution pattern, we turned our attention to the investigation of diene structures similar to successful endoperoxidation substrate 2a. Removal of

Table 2: Diene structure investigation for endoperoxidation cascade.

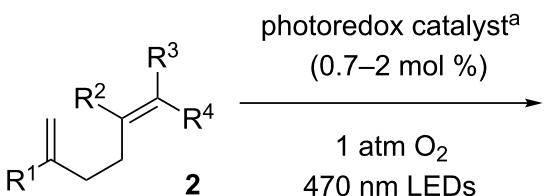

2

$470 \mathrm{~nm}$ LEDs<smiles>[R]C1CC2([R])COC1([R])C([R])C2</smiles>

or

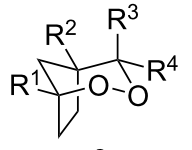

3

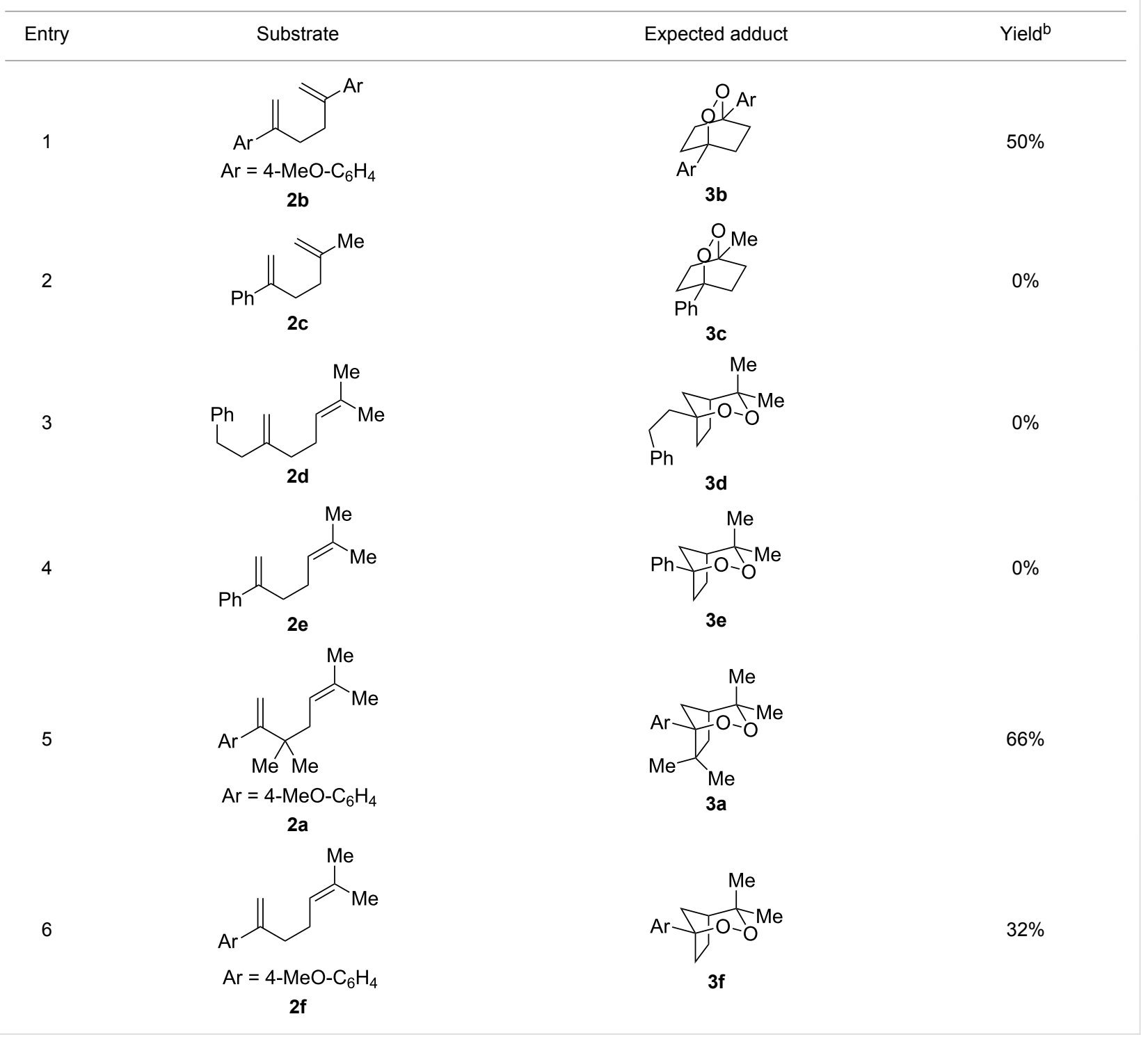


Table 2: Diene structure investigation for endoperoxidation cascade. (continued)

7<smiles>C=C([Al])CCC=C(C)C</smiles>

$\mathrm{Ar}=2,4-(\mathrm{MeO})_{2}-\mathrm{C}_{6} \mathrm{H}_{3}$

$2 \mathrm{~g}$<smiles>C=C([Al])CCC=C(C)C</smiles>

$\mathrm{Ar}=3,4-(\mathrm{MeO})_{2}-\mathrm{C}_{6} \mathrm{H}_{3}$

$\mathbf{2 h}$<smiles>C=C([Al])CCC=C(C)C</smiles>

$\mathrm{Ar}=2-\mathrm{MeO}-\mathrm{C}_{6} \mathrm{H}_{4}$

2i

10<smiles>C=C([Al])CCC=C(C)C</smiles>

$\mathrm{Ar}=4-\mathrm{Me}-\mathrm{C}_{6} \mathrm{H}_{4}$

2j<smiles>C=C([Al])CCC=C(C)C</smiles>

$\mathrm{Ar}=4-\mathrm{Cl}-\mathrm{C}_{6} \mathrm{H}_{4}$

2k

12<smiles>C=C([Al])CCC=C(C)C</smiles>

2I<smiles>CC1(C)OOC2([Al])CCC1C2</smiles>

$3 g$<smiles>CC1(C)OOC2([Al])CCC1C2</smiles>

3h<smiles>CC1(C)OOC2([Al])CCC1C2</smiles>

$3 \mathbf{i}$<smiles>CC1(C)OOC2([Al])CCC1C2</smiles>

3j<smiles>CC1(C)OOC2([Al])CCC1CC2[Si]</smiles>

$0 \%$

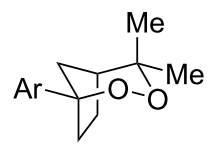

All reactions carried out in oxygen-saturated solvents. Solvents examined: $\mathrm{DCM}, \mathrm{CHCl}_{3}, \mathrm{MeCN}, \mathrm{PhMe}$, acetone. ${ }^{\mathrm{a} C a t a l y s t s} \mathbf{1 a}$, 1b, and $\mathbf{1 c}$ screened for reactivity with all substrates. ${ }^{\mathrm{b}}$ Average of two isolated yields.

the geminal dimethyl group (2f) resulted in significantly diminished yields of the endoperoxide adduct, likely due to the lack of a Thorpe-Ingold effect present in 2a. These experiments also demonstrated that the electron-rich arene was necessary for reactivity (cf. 2e and 2f; Table 2, entries 4 and 6). The importance of the electron-rich arene may lie in the necessary distonic cation radical intermediate: the electron-rich arene may provide greater stability to the distonic intermediate formed after 5-exotrig cyclization, ultimately ensuring it remains to intercept oxygen. A further survey of the styrene component supported this hypothesis. While electron-rich styrenes gave modest amounts of product formation (2f, $\mathbf{2} \mathbf{g}$ and $\mathbf{2} \mathbf{i}$; Table 2, entries 6 , 7 and 9), styrenes with either weakly donating (4-Me; Table 2, entry 10 ) or even withdrawing (4-Cl; Table 2, entry 11 ) functionality furnished none of the expected endoperdoxides. In these cases, oxidative degradation was observed as was the case with the highly oxidizable 2-furyl group (Table 2, entry 12). Interestingly, 3,4-dimethoxystyrene-substituted diene $\mathbf{2 h}$ also gave none of the desired adduct, which we attributed to lack of charge density on the alkene [28,29]. 
We next investigated the endoperoxidation cascade by replacing the isoprenyl substituent with a variety of other alkenes. A pendant styrene afforded the desired endoperoxide adduct in $68 \%$ yield, albeit with no diastereocontrol (2m, 1:1 dr; Table 3, entry 1). A diene bearing a tetrasubstituted alkene (2n) was reactive in this context, giving polycyclic endoperoxide $\mathbf{3 n}$ in $64 \%$ yield $(6.5: 1 \mathrm{dr})$. The use of 1,2-, 1,1-dialkyl as well as monoalkyl-substituted alkenes appeared to completely disfavor

Table 3: Variation of the tethered alkene component.

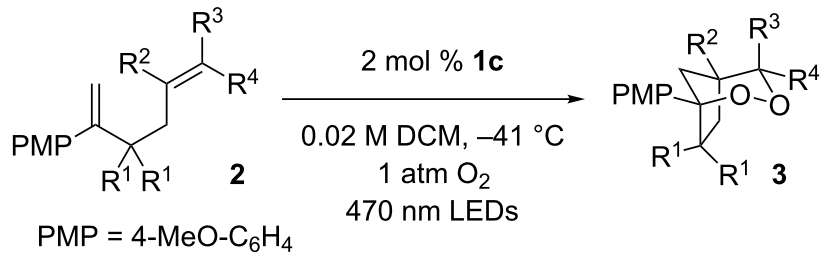

\begin{tabular}{|c|c|c|c|}
\hline Entry & Substrate & Observed product & Yielda $^{a}$ \\
\hline
\end{tabular}

$1^{b}$<smiles>C=C(N)C(C)(C)C/C=C/c1ccccc1</smiles>

2m

$2^{\mathrm{C}}$<smiles>C=C(P)C(C)(C)CC1=C(C)CCCC1(C)C</smiles>

2n

$3^{d}$<smiles>C=C(P)C(C)(C)C/C=C/C</smiles>

20

$4^{d}$<smiles>C=C(C)CC(C)(C)C(=C)P</smiles>

$2 p$

$5^{d}$<smiles>C=CCC(C)(C)C(=C)NCCC</smiles>

2q

$6^{e}$<smiles>C=C(CCC=CC)NC(=O)c1ccccc1</smiles>

$7^{\mathrm{e}}$<smiles>CC1(C)OC2(c3ccccc3)CCC1C21OOC1(C)C</smiles>

$68 \%, 1: 1$ d.r.<smiles>CC1(C)OC(C)(C)C(C)(C)OC2(CCCC2(C)C)O1</smiles>

$64 \%, 6.5: 1$ d.r.

$36 \%$

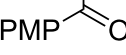

30

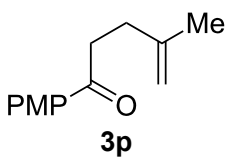<smiles>C=CCCC(=O)NCC</smiles>

$3 q$

Reactions carried out in oxygen-saturated solvents. aAverage of two isolated yields. ${ }^{b} 1: 1$ mixture of separable diastereomers. ${ }^{\mathrm{c}} 6.5: 1$ mixture of inseparable diastereomers. Presumed major diastereomer shown. ${ }^{\mathrm{d} D e s i r e d ~ e n d o p e r o x i d e ~ n e v e r ~ o b s e r v e d . ~}{ }^{\mathrm{P}}$ Multiple conditions tested, no productive chemistry observed. 
the endoperoxidation pathway and resulted in the unexpected isolation of $\alpha$-allyl ketones (Table 3, entries 3-5) in modest yields. Based on the Miyashi precedent, the formation of these adducts can be rationalized by invoking a formal $[3,3]-$ rearrangement of the initial cation radical intermediate. The competing 6-endo cyclization mode and formation of distonic cation radical 9 ultimately provides access to the more stabilized cation radical $\mathbf{1 0}$, which undergoes oxidative cleavage to afford the corresponding $\alpha$-allyl ketones (Scheme 4). In the absence of the geminal dimethyl group (2r, 2s), neither the Cope-like reactivity or the endoperoxidation was observed (Table 3, entries 6 and 7).

Lastly, we elected to explore cyclization modes similar to the Yoon work under the developed conditions. Diene $\mathbf{2 t}$ was anticipated to undergo 6-exo-trig cyclization to form the necessary distonic cation radical intermediate (Table 4, entry 1). The expected trioxabicyclo[3.3.1]nonane product was formed, albeit

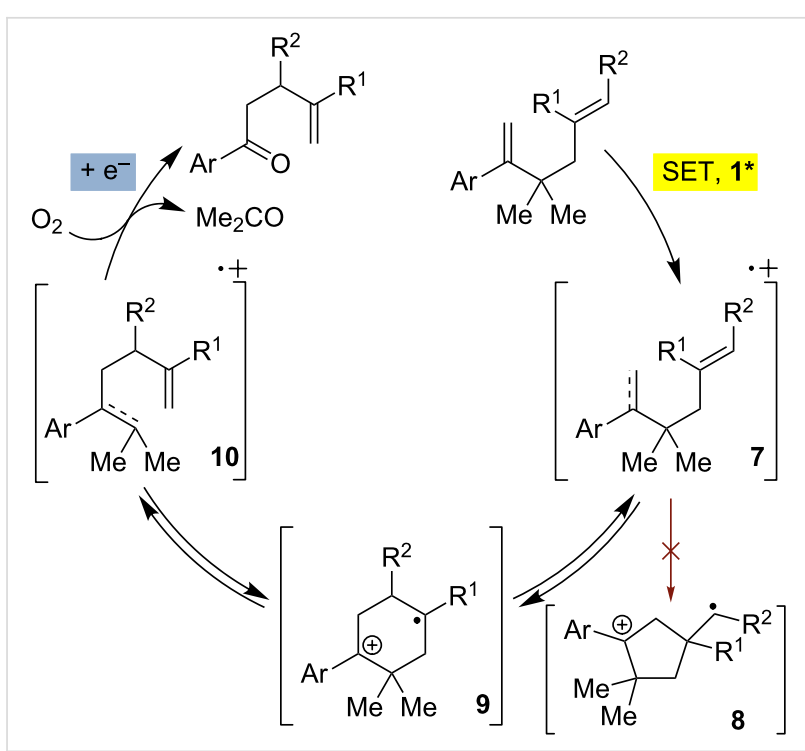

Scheme 4: Competing formal $[3,3]$ pathway.

Table 4: Other cyclization modes and substrate designs.

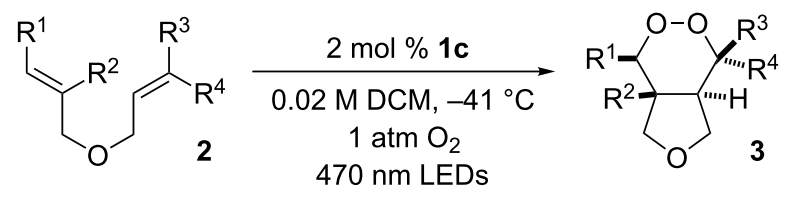

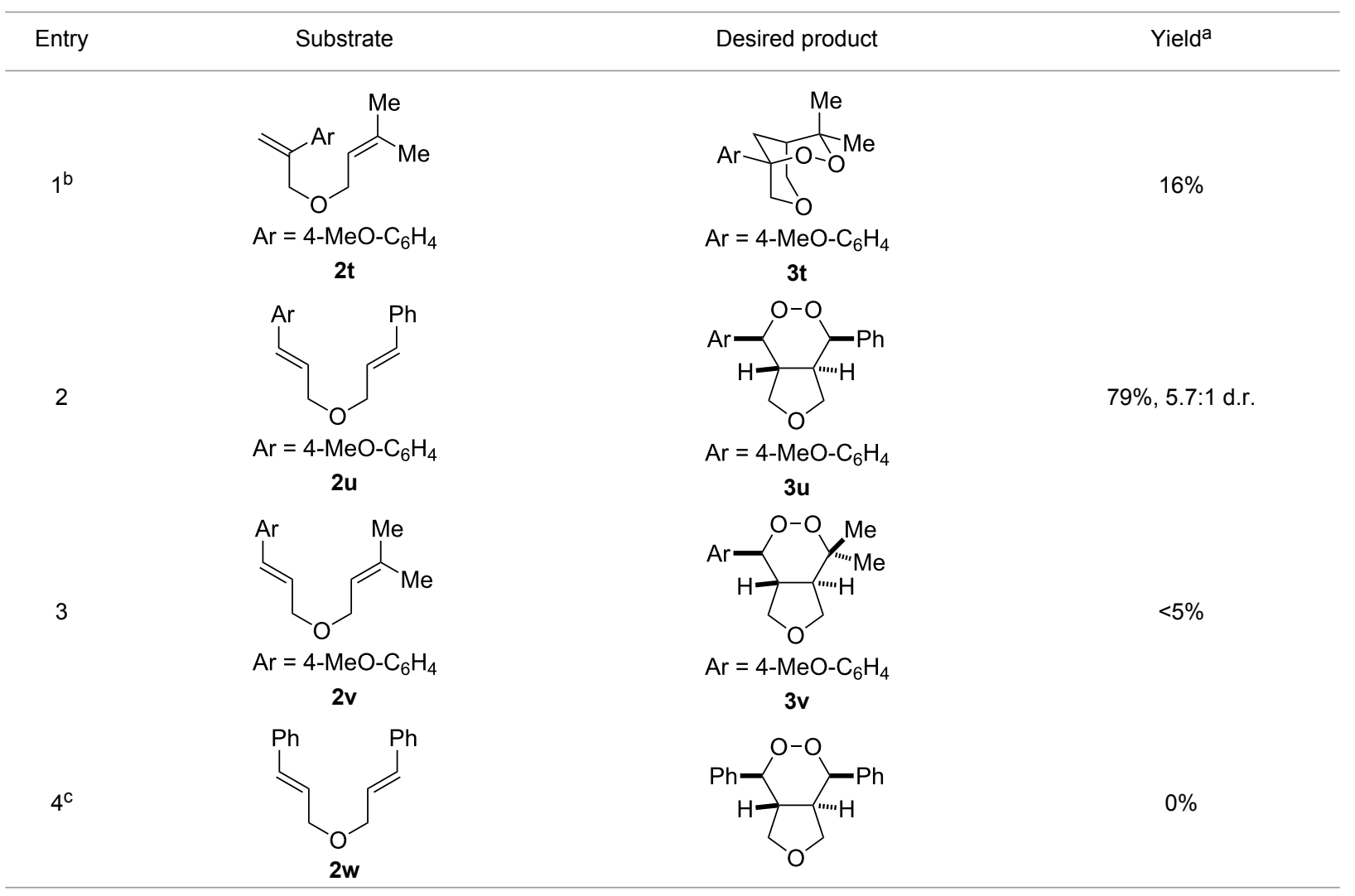

Reactions carried out in oxygen-saturated dichloromethane. aAverage of two isolated yields. ${ }^{b}$ Carried out in $0.4 \mathrm{M}$ DCE after solvent and concentration optimization. ${ }^{\mathrm{C} C a t a l y s t s ~} \mathbf{1 a}$ or $\mathbf{1 b}$ were also tested but failed to furnish the endoperoxide. 
in low yields $(16 \%)$, where the remainder of the mass balance was attributed to oxidative degradation.

Bis(styrene) $\mathbf{2 u}$ afforded the identical fused 1,2-dioxane observed in Yoon's report in 79\% yield (5.7:1 dr). Tethered trisubstituted aliphatic alkene substrate $\mathbf{2 v}$, along with bis(styrene) substrate $\mathbf{2} \mathbf{w}$ were unfortunately unsuccessful, producing neither of the desired fused 1,2-dioxane products in appreciable amounts. Degradation pathways were dominant for $\mathbf{2 v}$ and mainly unreacted starting material was observed $\mathbf{2 w}$.

\section{Conclusion}

In the presence of an organic single electron photooxidant, a variety of dienes were demonstrated to undergo a cyclization/ endoperoxidation cascade sequence to form 1,2-dioxanes. Requirements for successful diene reactivity are the presence of an oxidizable olefin and an alkene that can efficiently react with the putative alkene cation radical to form a more stable distonic cation radical. If available, a Cope-like pathway can compete and suppress endoperoxide formation. With these parameters in mind, this reaction could provide a platform for the discovery of novel biologically-active endoperoxides.

\section{Supporting Information}

\section{Supporting Information File 1}

Experimental procedures and characterization data. [http://www.beilstein-journals.org/bjoc/content/ supplementary/1860-5397-10-128-S1.pdf]

\section{Supporting Information File 2}

\section{X-ray data.}

[http://www.beilstein-journals.org/bjoc/content/ supplementary/1860-5397-10-128-S2.pdf]

\section{Acknowledgements}

We gratefully acknowledge the David and Lucile Packard Foundation for financial support. Additionally, we thank Nathan Romero for DFT calculations and Dr. Peter White for $\mathrm{X}$-ray analysis.

\section{References}

1. Ando, W., Ed. Organic Peroxides; John Wiley \& Sons: New York, 1992.

2. Dembitsky, V. M. Eur. J. Med. Chem. 2008, 43, 223-251. doi:10.1016/j.ejmech.2007.04.019

3. Li, H.; Huang, H.; Shao, C.; Huang, H.; Jiang, J.; Zhu, X.; Liu, Y.; Liu, L.; Lu, Y.; Li, M.; Lin, Y.; She, Z. J. Nat. Prod. 2011, 74, 1230-1235. doi:10.1021/np200164k

4. Chokpaiboon, S.; Sommit, D.; Bunyapaiboonsri, T.; Matsubara, K.; Pudhom, K. J. Nat. Prod. 2011, 74, 2290-2294. doi:10.1021/np200491g
5. Adio, A. M.; König, W. A. Phytochemistry 2005, 66, 599-609. doi:10.1016/j.phytochem.2005.01.015

6. Adam, W.; Griesbeck, A. G. In CRC Handbook of Organic Photochemistry and Photobiology; Horspool, W. M.; Song, P., Eds.; CRC Press: Boca Raton, 1992.

7. Bloodworth, A. J.; Eggelte, H. J. In Singlet Oxygen; Frimer, A. A., Ed.; CRC Press: Boca Raton, 1985; Vol. II.

8. Iesce, M. R. In Synthetic Organic Photochemistry; Griesbeck, A. G.; Mattay, J., Eds.; Marcel Dekker: New York; pp 299-363.

9. Harris, J. R.; Waetzig, S. R.; Woerpel, K. A. Org. Lett. 2009, 11, 3290-3293. doi:10.1021/ol901046z

10. Krabbe, S. W.; Do, D. T.; Johnson, J. S. Org. Lett. 2012, 14, 5932-5935. doi:10.1021/ol302848m

11. Rubush, D. M.; Morges, M. A.; Rose, B. J.; Thamm, D. H.; Rovis, T. J. Am. Chem. Soc. 2012, 134, 13554-13557. doi:10.1021/ja3052427

12. Miyashi, T.; Konno, A.; Takahashi, Y. J. Am. Chem. Soc. 1988, 110, 3676-3677. doi:10.1021/ja00219a062

13. Takahashi, Y.; Okitsu, O.; Ando, M.; Miyashi, T. Tetrahedron Lett. 1994, 35, 3953-3956. doi:10.1016/S0040-4039(00)76711-6

14. Kamata, M.; Ohta, M.; Komatsu, K.-i.; Kim, H.-S.; Wataya, Y. Tetrahedron Lett. 2002, 43, 2063-2067. doi:10.1016/S0040-4039(02)00166-1

15. Parrish, J. D.; Ischay, M. A.; Lu, Z.; Guo, S.; Peters, N. R.; Yoon, T. P. Org. Lett. 2012, 14, 1640-1643. doi:10.1021/ol300428q

16. Kamata, M.; Hagiwara, J.-i.; Hokari, T.; Suzuki, C.; Fujino, R.; Kobayashi, S.; Kim, H.-S.; Wataya, Y. Res. Chem. Intermed. 2013, 39, 127-137. doi:10.1007/s11164-012-0637-3

17. Narayanam, J. M. R.; Stephenson, C. R. J. Chem. Soc. Rev. 2011, 40, 102-113. doi:10.1039/b913880n

18. Xuan, J.; Xiao, W.-J. Angew. Chem., Int. Ed. 2012, 51, 6828-6838. doi:10.1002/anie.201200223

19. Prier, C. K.; Rankic, D. A.; MacMillan, D. W. C. Chem. Rev. 2013, 113, 5322-5363. doi:10.1021/cr300503r

20. Martiny, M.; Steckhan, E.; Esch, T. Chem. Ber. 1993, 126, 1671-1682. doi:10.1002/cber.19931260726

See for excited state reduction potential converted from $E$ vs NHE to $E$ vs SCE.

21. Miranda, M. A.; Garcia, H. Chem. Rev. 1994, 94, 1063-1089. doi:10.1021/cr00028a009

22. Kamata, M.; Kaneko, J.-i.; Hagiwara, J.-i.; Akaba, R. Tetrahedron Lett. 2004, 45, 7423-7428. doi:10.1016/j.tetlet.2004.08.077

23. Hamilton, D. S.; Nicewicz, D. A. J. Am. Chem. Soc. 2012, 134, 18577-18580. doi:10.1021/ja309635w

24. Fukuzumi, S.; Ohkubo, K. Chem. Sci. 2013, 4, 561-574. doi:10.1039/c2sc21449k

25. Nguyen, T. M.; Nicewicz, D. A. J. Am. Chem. Soc. 2013, 135 , 9588-9591. doi:10.1021/ja4031616

26. Perkowski, A. J.; Nicewicz, D. A. J. Am. Chem. Soc. 2013, 135, 10334-10337. doi:10.1021/ja4057294

27. Gaussian 09, Revision D.01; Gaussian, Inc.: Wallingford CT, 2013.

28. Riener, M.; Nicewicz, D. A. Chem. Sci. 2013, 4, 2625-2629. doi:10.1039/c3sc50643f

29. Yamashita, T.; Yasuda, M.; Isami, T.; Tanabe, K.; Shima, K. Tetrahedron 1994, 50, 9275-9286. doi:10.1016/S0040-4020(01)85505-8 


\section{License and Terms}

This is an Open Access article under the terms of the Creative Commons Attribution License

(http://creativecommons.org/licenses/by/2.0), which permits unrestricted use, distribution, and reproduction in any medium, provided the original work is properly cited.

The license is subject to the Beilstein Journal of Organic Chemistry terms and conditions:

(http://www.beilstein-journals.org/bjoc)

The definitive version of this article is the electronic one which can be found at:

doi:10.3762/bjoc. 10.128 